\title{
Diagnosis of hairy-cell leukaemia by tartrate-resistant acid phosphatase activity in paraffin-embedded tissue sections
}

\section{GROULS}

From the Institute of Pathology of the University of Bonn, Germany

SUMMARY Tartrate-resistant acid phosphatase activity may be demonstrated in paraffin-embedded liver and spleen specimens as well as in decalcified bone marrow biopsies after fixation in a mixed glutaraldehyde-formaldehyde-calcium acetate solution. This technique may routinely be applied to haematologically relevant material and aids in the differential diagnosis of hairy-cell leukaemia.

Jamshidi needle biopsies of the bone marrow are used extensively in the initial evaluation of patients with non-Hodgkin's lymphoma. Hairy-cell leukaemia has to be considered in the differential diagnosis of lymphoid myelofibrosis. A positive tartrate-resistant acid phosphatase activity of the cells usually establishes the diagnosis. In the following short

Received for publication 3 December 1979 communication the possibility of employing this marker enzyme also on paraffin-embedded decalcified bone marrow sections and other tissues is discussed.

\section{Methods}

Needle biopsy specimens of bone marrow from the iliac crest as well as liver and spleen tissues were

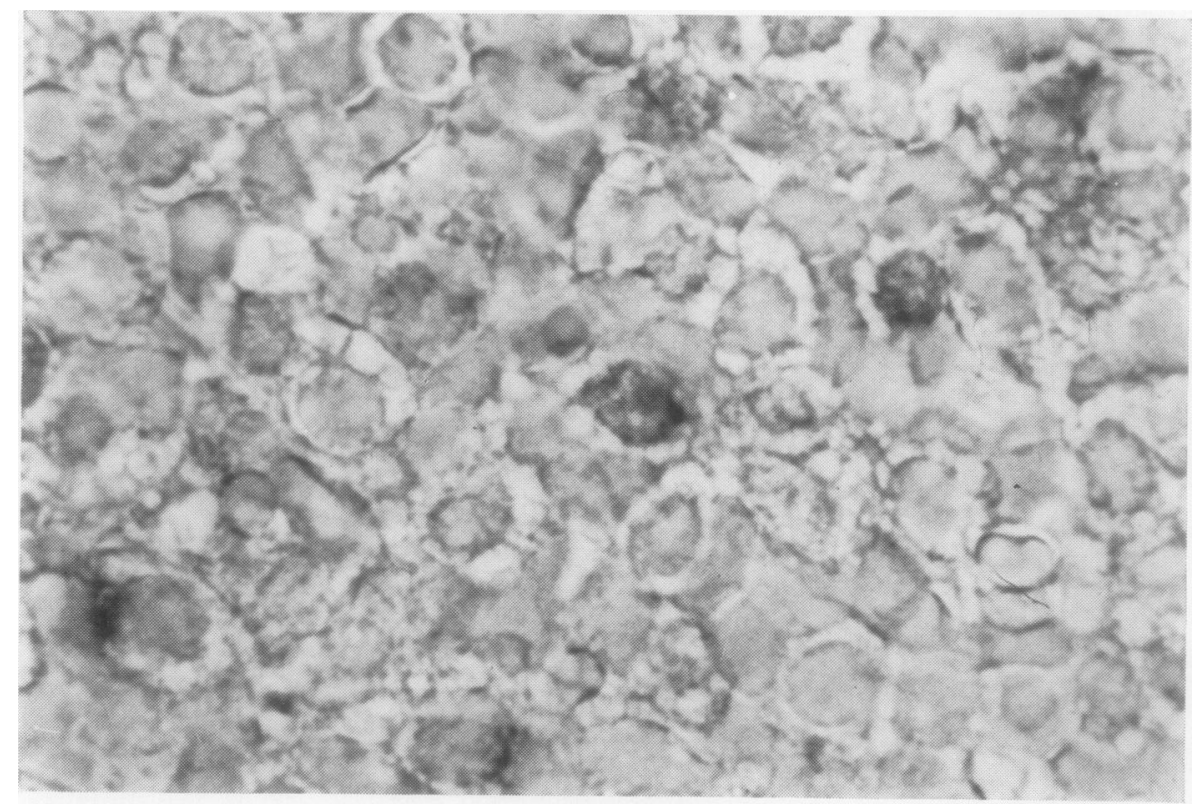

Fig. 1 Positive tartrate-resistant acid phosphatase activity in lymphoid cells. Decalcified, paraffin-embedded bone marrow; Jamshidi needle biopsy, no nuclear counterstaining $\times 1300$. 


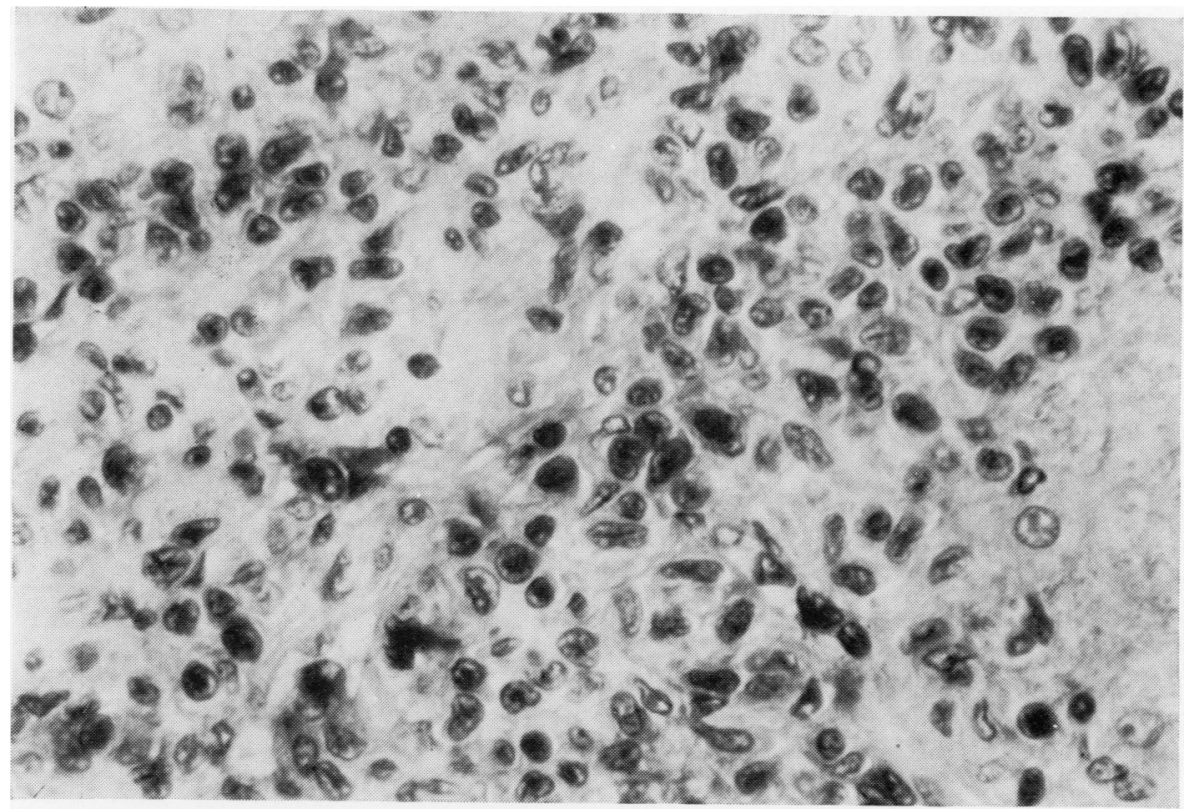

Fig. 2 Infiltration of a portal tract in hairy-cell leukaemia. Paraffin-embedded wedge biopsy of liver; positive cytoplasmic staining with tartrate-resistant acid phosphatase; nuclear counterstaining $\times 400$.

fixed in a solution containing $20 \mathrm{ml} 25 \%$ glutaraldehyde, $40 \mathrm{ml} 35 \%$ formaldehyde, and $15.8 \mathrm{~g}$ calciumacetate, made up to $1000 \mathrm{ml}$ with distilled water. ${ }^{1}$ Osseous structures were decalcified in a solution of $100 \mathrm{~g}$ EDTA and $33 \mathrm{~g}$ Tris buffer with distilled water added to $1000 \mathrm{ml}$ at room temperature for two to three days. ${ }^{2}$

The tartrate-resistant acid phosphatase reaction was carried out using naphthol-AS-BI-phosphate as a substrate and hexazonium pararosaniline as a coupler. ${ }^{3}$

\section{Results and comment}

Three cases of suspected hairy-cell leukaemia were investigated. In the first case, a Jamshidi bone marrow biopsy (Fig. 1), in the second a wedge excision of the liver (Fig. 2) as well as the removed spleen, and in the third the spleen only were examined. In every instance the typical diffuse bright red enzyme activity in the cytoplasm of the hairy cells is apparent, thus confirming the tricholeucocytic nature of these malignant lymphomas. An improved staining contrast will sometimes be obtained, especially in bone marrow biopsies without nuclear counterstaining. Furthermore, it is shown in Fig. 2 that the lymphoid infiltrate is not only located in the liver sinusoids but also to a great extent in the portal tracts. In the bone marrow, macrophages and osteoclasts exhibit a distinct positive reaction, but this may not pose any diagnostic problems as far as hairy-cell leukaemia is concerned.

From the practical point of view it may be stated that, besides AS-D-chloroacetate-esterase ${ }^{4}$ and peroxidase, ${ }^{5}$ acid phosphatase is the third cellular enzyme which may easily be applied in the examination of haematologically relevant paraffinembedded tissue material, and thus be used successfully in routine work. In suitable cases with a high enzyme content, it surely will be helpful in making the final diagnosis of hairy-cell leukaemia. But it should also be mentioned that both the fixation and decalcification of material in the solutions originally recommended by Schaefer $^{12}$ are necessary preconditions for an optimal staining result.

\section{References}

${ }^{1}$ Schaefer HE. 1978, personal communication.

${ }^{2}$ Schaefer HE, Hellriegel KP, Fischer R. Vorkommen von Tartrat-resistenter saurer Phosphatase in verschiedenen Zelltypen des lympho-retikulären und hämatopoetischen Systems. Blut 1977;34:393-7.

${ }^{3}$ Leder LD, Stutte HJ. Seminar für hämatologischzytochemische Techniken. Verh dtsch Ges Pathol 1975;59:503-9. 
${ }^{4}$ Leder LD. Der Nachweis von Naphthol-AS-DChloracetat Esterase und seine Bedeutung für die histologische Diagnostik. Verh dtsch Ges Pathol 1964;48:317-20.

${ }^{5}$ Schaefer HE, Fischer R. Der Peroxydasenachweis an Ausstrich-präparaten sowie an Gewebsschnitten nach Entkalkung und Paraffineinbettung. Klin Wschr 1968;46:1228-30.

Requests for reprints to: Dr V Grouls, Pathological Institute, University of Bonn, 53 Bonn 1, Germany. 